\title{
Pengaruh Risk Profile, Good Corporate Governance, Earnings Dan Capital Pada Perubahan Harga Saham Bank
}

\author{
Ni Putu Desy Wulandara Cahyani ${ }^{1}$ \\ I.G.A.M. Asri Dwija Putri ${ }^{2}$ \\ ${ }^{1}$ Fakultas Ekonomi dan Bisnis Universitas Udayana (Unud), Bali, Indonesia \\ email: desywulandara@gmail.com/ Telp.081353225384 \\ ${ }^{2}$ Fakultas Ekonomi dan Bisnis Universitas Udayana (Unud), Bali, Indonesia
}

\begin{abstract}
ABSTRAK
Penelitian ini dilakukan untuk mengetahui pengaruh risk profile, good corporate governance, earnings yang diukur dengan return on asset dan net interest margin serta capitalyang diukur dengan capital adequacy ratiopada perubahan harga saham bank. Penelitian dilakukan pada perusahaan perbankan yang terdaftar di Bursa Efek Indonesia tahun 2014-2016 dengan jumlah sampel sebanyak 28 perusahaan perbankan yang ditentukan dengan metode purposive sampling. Teknik analisis data yang digunakan adalah regresi linear berganda. Hasil penelitian ini menunjukan bahwa risk profile berpengaruh negatif pada perubahan harga saham bank. Good corporate governance, return on asset dan net interest margin berpengaruh positif pada perubahan harga saham bank. Capital adequacy ratio tidak berpengaruh pada perubahan harga saham bank.

Kata kunci: perubahan harga saham bank, risk profile, good corporate governance, return on asset
\end{abstract}

\begin{abstract}
The study is aimed to determine the effect of risk profile, good corporate governance, earnings measured by return on assets and net interest margin and capital measured by capital adequacy ratio on bank stock price changes. The research was conducted at the banking companies registered at the Indonesian Stock Exchange in 2014-2016 with the total samples of 28 banking companies determined by purposive sampling method. The data analysis technique used was multiple linear regression. The results of this study indicated that the risk profile has a negative effect of bank stock prices changes. Moreover, good corporate governance, return on assets and net interest margin has a positive effect of bank stock prices changes. The capital adequacy ratio has no effect on bank stock price changes.

Keywords: bank stock price changes, risk profile, good corporate governance, return on assets
\end{abstract}

\section{PENDAHULUAN}

Salah satu indikator keberhasilan pengelolaan perusahaan perbankan adalah harga saham. Harga saham suatu perusahaan mencerminkan keberhasilan dari keputusan-keputusan strategis keuangan perusahaan seperti keputusan pendanaan, keputusan investasi dan keputusan deviden. Hal ini akan direspon pasar dengan 
Ni Putu Desy Wulandara Cahyani dan I.G.A.M. Asri Dwija Putri. Pengaruh...

terjadinya transaksi perdagangan saham di pasar modal. Perubahan harga saham merupakan reaksi dari pasar dan aktivitas bisnis perbankan (Setyawan dan Mawardi, 2012).

Harga saham ditentukan oleh mekanisme pasar yang berlangsung secara terus menerus sehingga harga saham cenderung berfluktuatif. Perubahan harga saham dapat memberikan sinyal tentang kegairahan dan kelesuan aktivitas pasar modal serta pemodal dalam melakukan aksi jual beli saham. Terdapat beberapa faktor yang menyebabkan perubahan harga saham diantaranya faktor yang rasional dan irasional. Faktor yang sifatnya rasional mencakup kinerja perusahaan, tingkat bunga, tingkat inflasi, tingkat pertumbuhan, kurs valuta asing atau indeks harga saham negara lain, sedangkan faktor yang bersifat irrasional seperti sentimen pasar.

Informasi yang beredar di pasar seringkali ditanggapi seketika oleh investor, sehingga mempercepat reaksi pasar atas suatu informasi yang belum dapat dipastikan validitasnya. Beberapa waktu lalu terjadi penurunan harga saham sektor perbankan, yang disebabkan oleh kepanikan investor terkait rumor mengenai pembatasan margin bunga bersih (net interest margin) bank. Laba bank berpotensi mengalami penurunan dibanding tahun sebelumnya seiring dengan adanya pembatasan net interest margin. Otoritas Jasa Keuangan (OJK) tidak akan membatasi pendapatan bunga bersih bank, melainkan untuk menurunkan bunga kredit menjadi single digit yang dilakukan untuk meningkatkan pertumbuhan kredit nasional (infobank, 2016). 
Permintaan terhadap saham dipengaruhi oleh kinerja perusahaan. Kinerja suatu perusahaan tidak hanya dilihat berdasarkan kinerja keuangannya saja, melainkan dapat juga dilihat dari bagaimana citra perusahaan di mata masyarakat, manajemen perusahaan dan juga pengelolaan risiko dalam perusahaan. Kinerja yang baikhanya dapat dicapai apabila sumber daya yang dikuasai perusahaan dapat dikelola dengan efektif dan efisien (Bahri, 2014). Semakin baik kinerja suatu perusahaan, semakin banyak investor yang ingin membeli atau menyimpan dananya dalam suatu saham, maka harga saham tentunya akan semakin naik.

Ketika investor memutuskan untuk berinvestasi hal pertama yang akan dilakukan adalah mengevaluasi emiten mana yang akan ditanamkan modal investasi. Evaluasi dilakukan untuk mendapatkan informasi terkait atas investasi yang akan dipilih agar investor dapat memperoleh return yang maksimal. Investor tentu akan memilih perusahaan yang memiliki kinerja yang baik dan terus menunjukan peningkatan ditahun-tahun berikutnya. Hal ini mendorong perbankan Indonesia untuk terus meningkatkan kinerja perusahaannya yang pada penelitian ini diukur oleh tingkat kesehatan bank.

Investor akan menilai apakah bank dalam kondisi yang sehat atau tidak sehat. Jika investor yang dalam hal ini berperan sebagai penyedia dana mempunyai keraguan atas kesehatan bank, mereka cenderung akan menarik kembali dananya. Bank yang dapat menjaga kinerjanya dengan baik serta prospek usahanya dapat selalu berkembang dan memenuhi ketentuan prudential banking dengan baik, maka dapat dikatakan tingkat kesehatannya baik. Peraturan Otoritas Jasa Keuangan Nomor 4/POJK.03/2016 tentang Penilaian Tingkat Kesehatan 
Ni Putu Desy Wulandara Cahyani dan I.G.A.M. Asri Dwija Putri. Pengaruh...

Bank Umum menyatakan tingkat kesehatan bank adalah hasil penilaian kondisi bank yang dilakukan terhadap risiko dan kinerja bank. Penilaian ini berlandaskan pada prinsip- prinsip umum penilaian kesehatan bank yakni: berorientasi risiko, proporsionalitas, materialitas dan signifikansi serta komprehensif dan terstruktur.

Penilaian kesehatan bank sudah banyak mengalami perubahan, sejak diberlakukannya CAMEL (Capital, Asset, Management, Earnings dan Liquidity) pada tahun 1999, kemudian dirubah pada tahun 2004 menjadi CAMELS (Capital, Asset, Management, Earnings, Liquidity dan Sensitivity of Risk). Saat ini bank melakukan penilaian tingkat kesehatan bank menggunakan pendekatan risiko (risk-based banking rating) untuk menilai tingkat kesehatannya. Dengan metode ini bank menggunakan empat indikator yaitu RGEC (Risk Profile, Good Corporate Governance, Earnings dan Capital) yang menilai profil risiko perusahaan, tata kelola perusahaan yang baik, kemampuan bank untuk menghasilkan keuntungan dan kemampuan bank untuk memenuhi kecukupan modalnya.

Perubahan penilaian tingkat kesehatan bank dilakukan sejalan dengan semakin kompleksnya usaha dan profil risiko yang dihadapi bank, penerapan pengawasan secara konsolidasi serta perubahan pendekatan penilaian kondisi bank yang diterapkan secara internasional. Sistem penilaian kesehatan bank dengan menggunakan risk-based banking rating diharapkan bank mampu mengidentifikasi permasalahan secara lebih dini, melakukan tindak lanjut perbaikan yang sesuai serta menerapkan tata kelola perusahaan yang baik dan 
manajemen risiko yang lebih baik sehingga bank lebih tahan dalam menghadapi krisis.

Penilaian tingkat kesehatan bank secara umum diatur dalam Surat Edaran Otoritas Jasa Keuangan Nomor 14/SEOJK.03/2017 tentang Penilaian Tingkat Kesehatan Bank Umum yang merupakan petunjuk pelaksanaan dari Peraturan Otoritas Jasa Keuangan Nomor 4/POJK.03/2016 tentang Penilaian Tingkat Kesehatan Bank Umum, yang mewajibkan bank umum untuk melakukan penilaian sendiri (self assessment). Penilaian tingkat kesehatan bank menggunakan pendekatan risiko (risk-based bank rating) baik secara individual maupun secara konsolidasi.

Risk Profile merupakan penilaian terhadap risiko inheren dan kualitas penerapan manajemen risiko dalam operasional bank. Harga saham dapat mengalami penurunan apabila perusahaan sedang menghadapi risiko yang tinggi. Pasar saham bereaksi pada informasi profil risiko perusahaan perbankan (Indriani dan Dewi, 2016). Informasi ini membantu investor untuk menilai seberapa besar tingkat risiko yang dihadapi dan keefektifan penerapan manajemen risiko pada perusahaan tersebut.

Good corporate governance adalah suatu sistem yang mengatur hubungan antara para stakeholders demi tercapainya tujuan perusahaan. Peraturan Otoritas Jasa Keuangan Nomor 55/POJK.03/2016 tentang Penerapan Tata Kelola bagi Bank Umum menyatakan tata kelola yang baik adalah suatu tata cara pengelolaan bank yang menerapkan prinsip-prinsip keterbukaan (tranparency), akuntabilitas (accountability), pertanggung jawaban (resposibility), indepedensi (indepedency) 
Ni Putu Desy Wulandara Cahyani dan I.G.A.M. Asri Dwija Putri. Pengaruh...

dan kewajaran (fairness). Good corporate governance mempengaruhi nilai perusahaan dengan meningkatkan kinerja keuangan, mengurangi risiko yang mungkin dilakukan oleh dewan dengan keputusan-keputusan yang mementingkan diri sendiri dan meningkatkan kepercayaan investor (Annisa dan Wardhani, 2014).

Earnings atau rentabilitas merupakan salah satu dasar penilaian kinerja manajemen dalam mengelola kegiatan operasional bank. Rentabilitas bisnis perbankan adalah kesanggupan bisnis perbankan untuk mendapatkan laba berdasarkan investasi yang dilakukannya (Lestari dan Hermanto, 2015). Penilaian earnings dalam penelitian ini mencakup penilaian laba terhadap total aset yaitu return on asset dan net interest margin yang menggambarkan perbandingan antara pendapatan bunga bersih terhadap aktiva produktifnya.

Modal memiliki peranan yang penting bagi suatu perusahaan. Selain digunakan untuk kepentingan pengembangan usaha, juga digunakan sebagai penyangga (buffer) untuk menyerap kerugian kegiatan usaha. Penilaian atas faktor permodalan meliputi evaluasi terhadap kecukupan permodalan dan kecukupan pengelolaan permodalan. Peraturan Otoritas Jasa Keuangan Nomor 11/POJK.03/2016 tentang Kewajiban Penyediaan Modal Minimum Bank Umum mewajibkan bank untuk menyediakan modal minimum sesuai profil risiko. Semakin tinggi risiko yang dihadapi bank, maka semakin besar modal yang harus disediakan untuk mengantisipasi risiko tersebut. Penyediaan modal minimum dihitung dengan menggunakan rasio Kewajiban Penyediaan Modal Minimum (KPMM) atau yang lebih dikenal dengan Capital Adequacy Ratio (CAR). Capital adequancy ratio yang semakin meningkat menunjukkan kemampuan bank yang 
semakin baik dalam mempertahankan kecukupan modalnya untuk menjaga kualitas bank agar tetap sehat (Winarsih, 2016).

Penelitian mengenai pengaruh faktor-faktor tingkat kesehatan bank pada perubahan harga saham perbankan dengan menggunakan indikator RGEC (Risk Profile, Good Corporate Governance, Earnings dan Capital) terus mengalami perkembangan dan semakin dinamisnya pergerakan dunia perbankan saat ini, menimbulkan munculnya beberapa kebijakan- kebijakan baru yang disesuaikan dengan keadaan perekonomian Indonesia. Berdasarkan hal tersebut, maka tujuan dari penelitian ini adalah untuk menguji pengaruh risk profile, good corporate governance, earnings yang dalam penelitian ini dinilai dengan rasio return on asset dan net interest margin serta capital yang dinilai dengan capital adequancy ratio pada perubahan harga saham bank yang terdaftar di Bursa Efek Indonesia.

Semakin kompleksnya kegiatan usaha perbankan, menuntut bank untuk meningkatkan kebutuhan akan penerapan menejemen risiko. Pengelolaan risiko sangat penting karena menunjukan kualitas manajemen perusahaan (Hendrayana dan Yasa, 2015). Bagi investor pemahaman atas hubungan antara return dan risiko dalam investasi merupakan dasar dalam menentukan keputusan dalam investasi. Dengan penerapan manajemen risiko bank diharapkan dapat menjalankan seluruh kegiatan usahanya secara terintegrasi dalam suatu sistem pengelolaan risiko yang akurat dan komprehensif, sehingga dapat mengurangi dampak dari risiko pada setiap kegiatan usaha yang dilakukan. 
Ni Putu Desy Wulandara Cahyani dan I.G.A.M. Asri Dwija Putri. Pengaruh...

Penelitian yang dilakukan oleh Indriani dan Dewi (2016), Panjaitan dan Wardani (2016) serta Hendrayana dan Yasa(2015) menemukan bahwa risk profile memiliki pengaruh negatif pada harga saham. Hal ini menunjukan bila risiko yang dihadapi bank tinggi akan menyebabkan penurunan harga saham bank tersebut. Informasi terkait profil risiko akan membantu investor untuk mengetahui kemampuan bank dalam menghadapi risiko yang muncul dan keberhasilan penerapan manajemen risiko.

Kemampuan untuk mengukur risiko dan mengambil tindakan yang tepat merupakan kunci sukses berjalannya suatu perusahaan (Goyal dan Agrawal, 2010). Dengan pengelolaan risiko yang baik, membuat perusahaan tahan terhadap risiko yang akan timbul di masa depan. Hal ini akan membuat perusahaan dalam kondisi yang cukup stabil dan memberikan sinyal positif bagi investor untuk menanamkan modalnya pada bank. Profil risiko yang tinggi dianggap sebagai badnews oleh investor sehingga akan berdampak pada penurunan harga saham. Berdasarkan uraian diatas, maka hipotesis yang diajukan dalam penelitian ini adalah sebagai berikut:

$\mathrm{H}_{1}$ : Risk Profile berpengaruh negatif pada perubahan harga saham bank yang terdaftar di Bursa Efek Indonesia.

Setiap perusahaan harus memastikan bahwa good corporate governance sudah diterapkan pada setiap aspek bisnis dan disemua jajaran perusahaan. Dengan adanya sistem tata kelola perusahaan yang baik akan menjadikan aktivitas dalam suatu perusahaan berjalan dengan lebih efisien sehingga akan meningkatkan keuntungan yang diterima perusahaan yang berimbas pada peningkatan nilai perusahaan. Perusahaan yang memiliki tata kelola yang baik 
akan lebih diminati oleh investor, karena semakin baik tata kelola perusahaan perusahaan akan semakin meningkatkan kepercayaan investor pada perusahaan tersebut.

Penerapan asas-asas dalam good corporate governance dapat meningkatkan nilai perusahaan yang terlihat dari pergerakan harga saham, sebab seluruh kegiatan mereka diawasi oleh publik. Pelaksanaan good corporate governance yang baik dan sesuai dengan peraturan yang berlaku akan membuat investor memberikan respon positif terhadap kinerja perusahaan (Panjaitan dan Wardani, 2016). Tata kelola perusahaan memainkan peranan penting mendorong para pelaku di sektor jasa keuangan khususnya pasar modal untuk menjalankan kegiatan usahanya berdasarkan prinsip kewajaran, transparansi, akuntabilitas, tanggung jawab dan kemandirian untuk memperoleh kepercayaan investor atau pemangku kepentingan lainnya.

Penelitian yang dilakukan oleh Indriani dan Dewi (2016), Winarsih (2016), Luuet al. (2013) serta Hendrayana dan Yasa (2015) menemukan bahwa good corporate governance berpengaruh positif pada harga saham. Hasil penelitian ini membuktikan bahwa bila bank menerapkan seluruh aspek good corporate governance dengan baik akan meningkatkan kepercayaan masyarakat pada manajemen bank sehingga berdampak pada meningkatnya saham perbankan. Berdasarkan uraian diatas, maka hipotesis yang diajukan dalam penelitian ini adalah sebagai berikut:

$\mathrm{H}_{2}$ : Good corporate governance berpengaruh positif pada perubahan harga saham bank yang terdaftar di Bursa Efek Indonesia. 
Ni Putu Desy Wulandara Cahyani dan I.G.A.M. Asri Dwija Putri. Pengaruh...

Informasi terkait kemampuan suatu perusahaan untuk menghasilkan laba dalam periode tertentu tentu sangat menarik bagi stakeholders. Pemahaman terhadap informasi kemampulabaan suatu perusahaan dapat memberikan pandangan yang lebih baik dan mendalam tentang kinerja keuangan perusahaan, yang menjadi dasar untuk memprediksi posisi keuangan dan kinerja perusahaan masa depan. Penilaian earnings dalam penelitian menggunakan return on asset dan net interest margin.

Penelitian Indriani dan Dewi(2016), Hendrayana dan Yasa (2015), Lestari dan Hermanto (2015), Panjaitan dan Wardani (2016), Purnamasari et al.(2017) serta Purwasih dan Utomo (2010) menemukan bahwa return on asset berpengaruh positif pada harga saham. Peningkatan nilai return on assetakan berdampak pada calon investor dalam menilai perusahaan, sehingga dapat mempengaruhi penawaran terhadap saham perbankan. Penelitian lain yang dilakukan Wismaryanto (2013), Kurniadi (2012) serta Setyawan dan Mawardi (2012) menemukan bahwa net interest margin berpengaruh positif pada harga saham. Semakin tinggi nilai net interest margin maka harga saham juga akan meningkat. Tingginya rentabilitas suatu perusahaan akan memberikan sinyal positif bagi stakehoders, sehingga akan meningkatkan minat investor dalam investasi saham yang dapat meningkatkan harga saham perusahaan. Berdasarkan uraian diatas, maka hipotesis yang diajukan dalam penelitian ini adalah sebagai berikut:

$\mathrm{H}_{3}$ : Return on Asset berpengaruh positif pada perubahan harga saham bank yang terdaftar di Bursa Efek Indonesia. 
$\mathrm{H}_{4}$ : Net Interest Margin berpengaruh positif pada perubahan harga saham bank yang terdaftar di Bursa Efek Indonesia.

Untuk menjalankan setiap kegiatan bisnisnya perusahaan tentu memerlukan modal yang cukup. Manajemen bank harus memastikan bahwa bank memiliki kecukupan modal untuk mendukung kegiatan operasional dan mampu melakukan perencanaan kebutuhan permodalan untuk mendukung perkembangan usaha. Capital adequacy ratio mencerminkan kemampuan bank menutupi penurunan aktiva akibat terjadinya kerugian atas aktiva bank dengan menggunakan modalnya sendiri (Purnamasari et al., 2017). Pemenuhan kecukupan modal diperlukan untuk mengontrol risiko yang muncul dengan seluruh modal yang dimiliki bank. Nilai capital adequacy ratio yang positif menunjukan bank tersebut memiliki modal yang kuat, sehingga mampu untuk mengatasi kerugian yang dihadapi bank (Widyaningrum dan Asih, 2014).

Penelitian yang dilakukan Winarsih (2016), Kurniadi (2012), Satria dan Hatta (2015) serta Lestari dan Hermanto (2015) menemukan bahwa capital adequacy ratio berpengaruh positif pada harga saham. Capital adequancy ratio yang semakin meningkat menunjukan semakin baiknya kemampuan bank dalam menjaga ketersediaan modal yang berpengaruh terhadap kenaikan harga saham perbankan. Semakin baik bank mempertahankan capital adequacy ratioakan menjadi informasi yang positif bagi penanam modal, sehingga akan mempengaruhi permintaan dan atau penawaran saham bank tersebut. Berdasarkan uraian diatas, maka hipotesis yang diajukan dalam penelitian ini adalah sebagai berikut: 
Ni Putu Desy Wulandara Cahyani dan I.G.A.M. Asri Dwija Putri. Pengaruh...

$\mathrm{H}_{5}$ : Capital Adequacy Ratio berpengaruh positif pada perubahan harga saham bank yang terdaftar di Bursa Efek Indonesia.

\section{METODE PENELITIAN}

Penelitian ini menggunakan pendekatan kuantitatif yang berbentuk asosiatif atau sering disebut hubungan sebab akibat. Penelitian ini dilakukan pada perusahaan perbankan yang telah go public di Indonesia. Alasan peneliti memilih perusahaan perbankan karena saham sektor perbankan merupakan salah satu penggerak bursa saham dan karena peluang kenaikan saham perbankan yang masih cukup besar. Selain ituterdapat peraturan baru terkait penilaian kesehatan bank dengan menggunakan metode risk-based banking rating dengan indikator penilaian menggunakan risk profile, good corporate governance, earnings dan capital, sehingga diperlukan sedikit penyesuaian terhadap penilaian tingkat kesehatan bank. Perusahaan perbankan yang telah go public dapat dilihat di bursa efek Indonesia dan dapat diakses melalui website http://www.idx.co.id/.

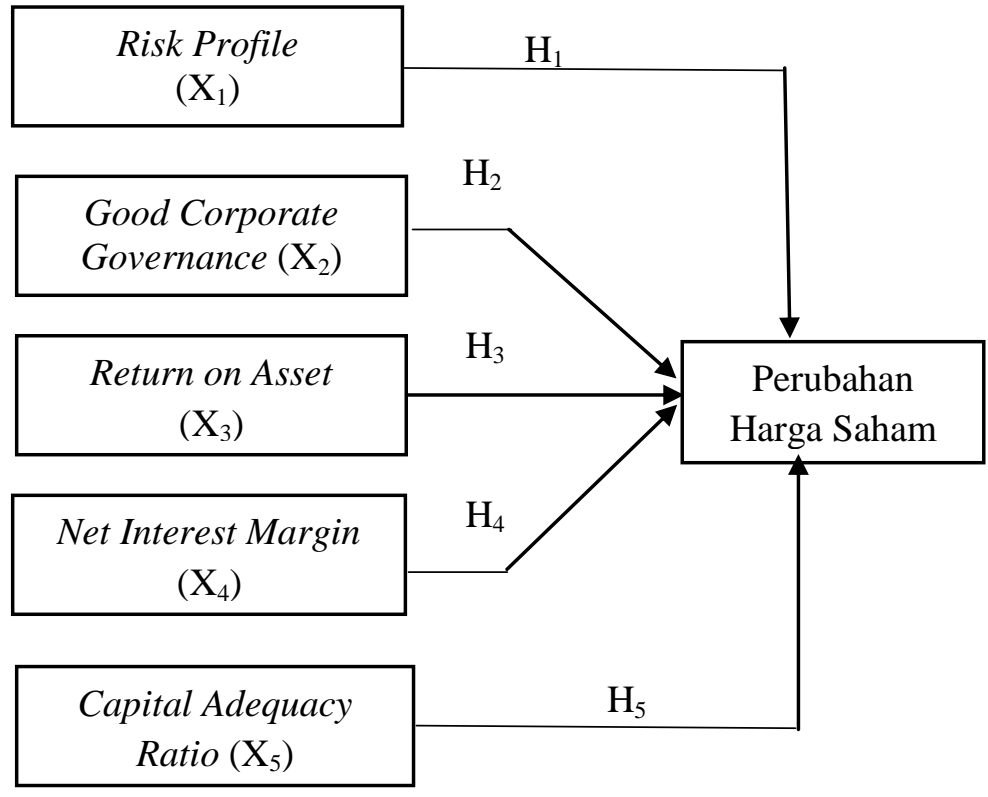

Gambar 1. Desain Penelitian 
Variabel bebas dalam penelitian ini adalah risk profile (X1), good corporate governance (X2), return on asset (X3), net interest margin (X4) dan capital adequacy ratio (X5). Risk profile dinilai berdasarkan hasil dari self assessment yang dilakukan masing-masing bank yang berupa peringkat akhir hasil penelitian risk profile yang didasarkan pada penilaian risiko inheren dan kualitas penerapan manajemen risiko. Good corporate governance dinilai berdasarkan hasil dari self assessment yang dilakukan masing-masing bank yang berupa peringkat akhir hasil penelitian good corporate governance yang didasarkan pada penilaian atas pelaksanaan prinsip-prinsip transparency, accountability, responsibility, independency dan fairness. Penilaian earnings dalam penelitian ini menggunakan rasio keuangan. Rasio digunakan untuk memperoleh informasi perkembangan finansial suatu perusahaan. Rasio keuangan yang digunakan dalam penelitian ini adalah return on asset dan net interest margin. Sedangkan penilaian capital yang terkait dengan penyediaan modal minimum dalam penelitian ini diukur menggunakan capital adequacy ratio.

Variabel terikat dalam penelitian ini adalah perubahan harga saham (Y). Perubahan harga saham menunjukan kenaikan dan penurunan harga saham. Harga saham yang dimaksud dalam penelitian ini adalah harga penutupan (closing price) masing perusahaan perbankan selama tahun penelitian.

Populasi dalam penelitian ini adalah keseluruhan perusahaan perbankan yang telah go public di Indonesia. Total keseluruhan perusahaan perbankan yang go public hingga 31 Desember 2016 adalah sebanyak 43 bank. Sampel yang 
Ni Putu Desy Wulandara Cahyani dan I.G.A.M. Asri Dwija Putri. Pengaruh...

digunakan dalam penelitian ini adalah perusahaan yang konsisten terdaftar di Bursa Efek Indonesia selama periode penelitian yakni sejak 2014 hingga 2016. Metode pengumpulan sampel yang dipakai dalam penelitian ini adalah metode purposive sampling. Pengambilan sampel dengan metode ini berdasarkan pada karakteristik tertentu yang dianggap mempunyai hubungan dengan karakteristik populasi yang sudah diketahui sebelumnya dengan pertimbangan bahwa perusahaan perbankan yang akan diteliti adalah perusahaan perbankan yang terdaftar di Bursa Efek Indonesia dan telah menerbitkan harga saham perdana (IPO) sebelum tahun 2013 yang memiliki kelengkapan informasi terkait peringkat profil risiko dan data mengenai nilai komposit penilaian good corporate governance.

Teknik analisis data yang digunakan untuk menjawab rumusan masalah dan menguji hipotesis yang telah diajukan dalam penelitian ini adalah analisis linear berganda. Analisis Regresi dilakukan untuk mengetahui hubungan antara satu atau beberapa variabel independen dengan sebuah variabel dependen. Secara matematis hubungan antara variabel independen dan variabel dependen dapat dijabarkan sebagai berikut:

$\mathrm{Y}=\alpha+\beta_{1} \mathrm{X}_{1}+\beta_{2} \mathrm{X}_{2}+\beta_{3} \mathrm{X}_{3}+\beta_{4} \mathrm{X}_{4}+\beta_{5} \mathrm{X}_{5}+\mathrm{e}$

Keterangan:

Y : Perubahan harga saham

$\mathrm{X}_{1} \quad$ : Risk Profile

$\mathrm{X}_{2} \quad$ : Good Corporate Governance

$\mathrm{X}_{3} \quad$ : Return on Asset

$\mathrm{X}_{4} \quad$ : Net Interest Margin

$\mathrm{X}_{5} \quad$ : Capital Adequacy Ratio

$\alpha \quad$ : Intercept

e : eror 


\section{HASIL DAN PEMBAHASAN}

Pengujian statistik deskriptif digunakan untuk menganalisis data dengan memberikan deskripsi terhadap suatu data mengenai nilai rata-rata, standar deviasi, nilai maksimum dan nilai minimum tanpa bermaksud membuat kesimpulan yang berlaku untuk umum atau generalisasi.

Tabel 1.

Statistik Deskriptif Variabel Penelitian

\begin{tabular}{|c|c|c|c|c|c|}
\hline Variabel & $\mathbf{N}$ & Minimum & $\begin{array}{c}\text { Maksimu } \\
\text { m }\end{array}$ & $\begin{array}{c}\text { Rata- } \\
\text { rata }\end{array}$ & $\begin{array}{c}\text { Std. } \\
\text { Deviasi }\end{array}$ \\
\hline Risk Profile $\left(\mathrm{X}_{1}\right)$ & 84 & 1,0000 & 4,0000 & 2,1310 & 0,4042 \\
\hline Good Corporate Governance $\left(\mathrm{X}_{2}\right)$ & 84 & 1,0000 & 4,0000 & 2,0119 & 0,5487 \\
\hline Return on Asset $\left(\mathrm{X}_{3}\right)$ & 84 & $-0,1115$ & 0,0473 & 0,0092 & 0,0269 \\
\hline Net Interest Margin $\left(\mathrm{X}_{4}\right)$ & 84 & 0,0024 & 0,1200 & 0,0516 & 0,0219 \\
\hline Capital Adequacy Ratio $\left(\mathrm{X}_{5}\right)$ & 84 & 0,0802 & 0,3450 & 0,1815 & 0,0399 \\
\hline Perubahan Harga Saham (Y) & 84 & $-0,5020$ & 1,7635 & 0,1025 & 0,3471 \\
\hline
\end{tabular}

Sumber: Data diolah, 2017

Risk profile merupakan penilaian terhadap risiko inheren dan kualitas penerapan manajemen risiko perusahaan perbankan. Hasil statistik deskriptif menunjukan nilai rata-rata (mean) data variabel risk profile sebesar 2,131 yang mengindikasikan bahwa rata-rata perusahaan yang menjadi sampel penelitian menghadapi risiko inheren dengan kategori rendah dan menerapkan manajemen risiko yang memadai. Nilai standar deviasi sebesar 0,4042 yang menunjukan bahwa standar penyimpangan data terhadap nilai rata-ratanya sebesar 0,4042. Nilai minimum selama tahun pengamatan sebesar 1,00 hasil ini menunjukan peringkat 1 dengan kriteria risiko inheren yang dihadapi bank tergolong sangat rendah dan penerapan manajemen risiko yang sangat memadai. Nilai maksimum 
Ni Putu Desy Wulandara Cahyani dan I.G.A.M. Asri Dwija Putri. Pengaruh...

selama tahun pengamatan sebesar 4,00 hasil ini menunjukan peringkat 4 dengan kriterian risiko inheren yang dihadapi bank tergolong tinggi dan penerapan manajemen risiko yang kurang memadai.

Good corporate governance adalah suatu proses dan struktur yang digunakan oleh orang-orang yang berkepentingan untuk meningkatkan keberhasilan usaha dan akuntabilitas perusahaan guna mewujudkan nilai pemegang saham dalam jangka panjang dengan tetap memperhatikan kepentingan stakeholder lainnya. Hasil statistik deskriptif menunjukan nilai rata-rata (mean) data variabel good corporate governance sebesar 2,012 hal ini mengindikasikan bahwa rata-rata perusahaan yang menjadi sampel penelitian melaksanakan good corporate governance dengan baik. Dengan standar deviasi sebesar 0,5487 yang menunjukan bahwa standar penyimpangan data terhadap nilai rata-ratanya sebesar 0,5487. Nilai minimum data variabel good corporate governance selama tahun pengamatan sebesar 1,00 nilai ini menunjukan bahwa pelaksanaan good corporate governance dilakukan dengan sangat baik. Nilai maksimum data variabel good corporate governance selama tahun pengamatan sebesar 4,00 nilai ini menunjukan bahwa kategori pelaksanaan good corporate governance kurang baik

Return on asset merupakan rasio yang menunjukan besarnya keuntungan yang diperoleh bank terhadap keseluruhan aset yang dimiliki. Hasil statistik deskriptif menunjukan nilai rata-rata data variabel return on asset sebesar 0,009210 atau $0,92 \%$ menunjukan bahwa perusahaan sampel memiliki kemampuan memperoleh keuntungan sebesar 0,92\% dari total aset yang dimiliki dalam satu periode. Dengan standar deviasi sebesar 0,026915 menunjukan bahwa 
standar penyimpangan data terhadap nilai rata-ratanya sebesar 0,026915 . Nilai maksimum pada penelitian ini sebesar 0,0473 atau $4,73 \%$, nilai ini terletak pada rentang sangat memadai. Sedangkan nilai minimum pada penelitian ini sebesar 0,1115 atau $-11,15 \%$, nilai ini terletak pada rentang tidak memadai. Hasil ini menunjukan bahwa terdapat perusahaan perbankan dalam penelitian ini yang masih memiliki tingkat return on asset dibawah ketentuan Otoritas Jasa Keuangan yaitu $1,25 \%$.

Net interest margin merupakan rasio yang menunjukan besarnya pendapatan bunga bersih yang diperoleh bank terhadap aset produktif yang dimiliki. Hasil statistik deskriptif menunjukan nilai rata-rata data variabel net interest margin sebesar 0,051639 atau 5,16\%, menunjukan bahwa perusahaan sampel memiliki kemampuan memperoleh pendapatan bunga bersih sebesar 5,16\% dari total aset produktif yang dimiliki dalam satu periode. Dengan standar deviasi sebesar 0,021871 menunjukan bahwa standar penyimpangan data terhadap nilai rataratanya sebesar 0,021871 . Nilai maksimum pada penelitian ini sebesar 0,12 atau $12 \%$, nilai ini terletak pada rentang sangat memadai. Sedangkan nilai minimum pada penelitian ini sebesar 0,0024 atau 0,24\%, nilai ini terletak pada rentang tidak memadai. Hasil ini menunjukan bahwa terdapat perusahaan perbankan dalam penelitian ini yang masih memiliki tingkat net interest margin dibawah ketentuan Otoritas Jasa Keuangan yaitu $2 \%$.

Capital adequacy ratio menunjukan besarnya kecukupan modal minimum yang dibutuhkan untuk dapat menutupi risiko kerugian yang mungkin timbul dari penanaman aktiva-aktiva yang mengandung risiko (kredit, penyertaan surat 
Ni Putu Desy Wulandara Cahyani dan I.G.A.M. Asri Dwija Putri. Pengaruh...

berharga dan tagihan pada pihak lain). Hasil dari statistik deskriptif menunjukan nilai rata-rata sebesar 0,1815 atau $18,15 \%$ menunjukan bahwa rata-rata perusahaan yang menjadi sampel penelitian memiliki tingkat kecukupan modal yang sangat memadai. Nilai standar deviasi sebesar 0,039875 menunjukan bahwa standar penyimpangan data terhadap nilai rata-ratanya sebesar 0,039875 . Nilai maksimum pada penelitian ini sebesar 0,3450 atau $34,50 \%$, nilai ini terletak pada rentang sangat memadai. Sedangkan nilai minimum pada penelitian ini sebesar 0,0802 atau $8,02 \%$, nilai ini terletak pada rentang cukup memadai. Hasil ini menunjukan bahwa perusahaan perbankan dalam penelitian ini memiliki nilai capital adequacy ratio yang sesuai dengan batas minimum yang ditetapkan oleh Otoritas Jasa Keuangan, yaitu 8\%.

Hasil dari statistik deskriptif menunjukan nilai rata-rata dari perubahan harga saham adalah sebesar sebesar 0,1025 dan standar deviasi sebesar 0,3471 menunjukan bahwa standar penyimpangan data terhadap nilai rata-ratanya sebesar 0,3471 . Nilai maksimum dari perubahan harga saham sebesar 1,7635 yang artinya kenaikan harga saham perusahaan perbankan dapat mencapai 176,35\%, kenaikan harga saham ini terjadi karena adanya respon positif dari investor dengan membeli saham perusahaan tersebut. Sedangkan nilai minimum pada penelitian ini sebesar -0,5020 yang artinya penurunan harga saham perusahaan dapat mencapai $50,20 \%$, penurunan harga saham terjadi karena adanya respon negatif dari investor dengan menjual saham perusahaan tersebut.

Analisis regresi dilakukan untuk mengetahui hubungan antara satu atau beberapa variabel independen dengan sebuah variabel dependen. 
Tabel 2.

Hasil Analisis Regresi Linear Berganda

\begin{tabular}{|c|c|c|c|c|c|}
\hline \multirow[t]{2}{*}{ Model } & \multicolumn{2}{|c|}{$\begin{array}{l}\text { Unstandardized } \\
\text { Coefficients }\end{array}$} & \multirow{2}{*}{$\begin{array}{c}\text { Standardized } \\
\text { Coefficients }\end{array}$} & \multirow[t]{2}{*}{$\mathbf{t}$} & \multirow[t]{2}{*}{ Sig. } \\
\hline & B & $\begin{array}{l}\text { Std. } \\
\text { Error }\end{array}$ & & & \\
\hline 1 (Constant) & 0,104 & 0,075 & & 1,390 & 0,169 \\
\hline Risk Profile & $-0,124$ & 0,060 & $-0,145$ & $-2,081$ & 0,041 \\
\hline Good Corporate & 0,404 & 0,083 & 0,377 & 4,882 & 0,000 \\
\hline Governance & & & & & \\
\hline Return on Assets & 0,365 & 0,076 & 0,358 & 4,791 & 0,000 \\
\hline Net Interest Margin & 0,232 & 0,076 & 0,224 & 3,054 & 0,003 \\
\hline Capital Adequacy Ratio & 0,055 & 0,070 & $-0,054$ & 0,789 & 0,433 \\
\hline F hitung & \multicolumn{2}{|c|}{31,569} & & & \\
\hline Signifikansi F & \multicolumn{2}{|c|}{0,000} & & & \\
\hline $\mathrm{R}$ Square & \multicolumn{2}{|c|}{0,669} & & & \\
\hline Adjusted R Square & \multicolumn{2}{|c|}{0,648} & & & \\
\hline
\end{tabular}

Sumber: Data diolah, 2017

Hasil analisis regresi linear berganda membentuk model persamaan regresi sebagai berikut.

Harga saham $=0,104-0,124 X_{1}+0,404 X_{2}+0,365 X_{3}+0,232 X_{4}+0,055 X_{5}$

Uji signifikansi simultan atau uji statistik $\mathrm{F}$ digunakan untuk mengetahui hubungan antara variabel independen secara simultan terhadap variabel dependen dengan taraf nyata $(\alpha)$ sebesar $5 \%$. Uji statistik $\mathrm{F}$ menunjukan apakah semua variabel bebas yang diidentifikasi (risk profile, good corporate governance, return on assets, net interest margin dan capital adequacy ratio ) tepat digunakan memprediksi perubahan harga saham.

Nilai koefisien uji $\mathrm{F}$ sebesar 31,569 dengan tingkat signifikansi sebesar 0,000. Oleh karena tingkat signifikansi 0,000 lebih kecil dari taraf signifikansi $(\alpha)$ sebesar 0,05 maka dapat disimpulkan bahwa model penelitian layak digunakan sebagai model regresi. Hasil ini mempunyai arti bahwa ada pengaruh signifikan antara faktor risk profile, good corporate governance, return on assets, net 
Ni Putu Desy Wulandara Cahyani dan I.G.A.M. Asri Dwija Putri. Pengaruh...

interest margin dan capital adequacy ratio secara simultan terhadap perubahan harga saham.

Koefisien determinasi dilakukan untuk mengetahui dan mengukur kemampuan model dalam menerangkan variasi variabel dependen. Nilai adjusted $\mathrm{R}^{2}$ sebesar 0,648 atau $64,8 \%$. Ini berarti variasi harga saham dapat dipengaruhi secara signifikan oleh variabel risk profile, good corporate governance, return on assets, net interest margin dan capital adequacy ratio sebesar 64,8\% sedangkan sisanya sebesar $35,2 \%$ dijelaskan oleh faktor-faktor lain yang tidak dimasukan ke dalam model regresi.

Risk profile berpengaruh negatif terhadap perubahan harga saham bank. Hal ini berarti hipotesis pertama $\left(\mathrm{H}_{1}\right)$ dalam penelitian ini dapat diterima, yaitu semakin tinggi risiko yang dihadapi bank tanpa adanya penerapan manajemen risiko yang memadai akan berdampak pada penurunan harga saham bank. Hal ini menunjukan bahwa informasi terkait risk profile suatu perusahaan merupakan salah satu pertimbangan investor dalam melakukan keputusan investasi. Informasi risk profile suatu perusahaan akan membantu investor untuk menilai kemampuan bank dalam menghadapi risiko yang muncul dalam kegiatan operasionalnya dan keberhasilan penerapan manajemen risiko sebagai tindak lanjut penanganan risiko yang timbul di dalam perusahaan. Oleh karena itu dibutuhkan penerapan manajemen risiko yang terintegrasi sehingga dapat meningkatkan kinerja suatu perusahaan, kinerja perusahaan yang baik akan berdampak pada meningkatnya ketertarikan investor untuk melakukan investasi pada perusahaan tersebut. Shareholder dapat kehilangan kepercayaannya dan tidak ingin untuk melanjutkan 
kerja sama dengan perusahaan, bila perusahaan tersebut tidak mampu untuk mengelola risiko dan menunjukan indikasi risiko kebangkrutan (Mohammed dan Knápková, 2016). Oleh karena itu pengelolaan risiko perusahaan memiliki pengaruh yang kuat terhadap keinginan shareholder untuk berinvestasi pada perusahaan.

Hasil penelitian ini konsisten dengan hasil penelitian yang dilakukan oleh Indriani dan Dewi (2016), Panjaitan dan Wardani (2016), serta Hendrayana dan Yasa (2015) yang menyatakan bahwa semakin tinggi tingkat risiko yang dihadapi oleh bank maka akan berdampak pada penurunan harga saham bank. Tingginya tingkat risiko yang dihadapi oleh bank akan memberikan sinyal yang negatif bagi investor, sehingga membuat investor menarik kembali modalnya dan berdampak pada penurunan harga saham.

Good corporate governance berpengaruh positif terhadap perubahan harga saham bank. Hal ini berarti hipotesis kedua $\left(\mathrm{H}_{2}\right)$ dalam penelitian ini dapat diterima, yaitu semakin baik penerapan good corporate governance yang dilakukan perusahaan perbankan akan berdampak pada kenaikan harga sahamnya. Good corporate governance akan menjadikan aktivitas yang dilakukan dalam perusahaan berjalan dengan lebih efisien yang akan berimbas pada peningkatan kinerja perusahaannya. Good corporate governance merupakan suatu sistem kebijakan, aturan dan faktor yang dapat mengendalikan operasional perusahaan (Luu et al., 2013). Oleh karena itu dengan penerapan good corporate governance dalam pengelolaan perusahaan diharapkan dapat meningkatkan kinerja keuangan, meminimalisir risiko yang mungkin dilakukan oleh pihak manajemen perusahaan 
Ni Putu Desy Wulandara Cahyani dan I.G.A.M. Asri Dwija Putri. Pengaruh...

dengan keputusan-keputusan yang mementingkan diri sendiri dan meningkatkan kepercayaan investor.

Hasil penelitian ini konsisten dengan hasil penelitian yang dilakukan oleh Indriani dan Dewi (2016), Hendrayana dan Yasa (2015), Winarsih (2016) sertaLuu et al. (2013) yang menyatakan bahwa semakin baik penerapan good corporate governance dalam suatu perusahaan akan berdampak pada kenaikan harga saham bank. Hal ini dikarenakan keberhasilan penerapan good corporate governance direspon dengan baik oleh investor melalui pembelian saham yang berdampak pada kenaikan harga saham bank.

Return on assets berpengaruh positif terhadap perubahan harga saham bank. Hal ini berarti hipotesis ketiga $\left(\mathrm{H}_{3}\right)$ dalam penelitian ini dapat diterima, yaitu semakin tinggi nilai return on asset berdampak pada kenaikan harga saham bank. Informasi terkait keberhasilan suatu perusahaan untuk menghasilkan laba pada periode tertentu sangat menarik perhatian investor. Return on asset menunjukan efisiensi manajemen dalam menggunakan aset yang dimiliki perusahaan untuk meningkatkan keuntungan (Muhammad dan Scrimgeour, 2014). Nilai return on asset yang semakin besar menunjukan bahwa kemampuan perusahaan untuk menghasilkan keuntungan meningkat, yang berdampak pada peningkatan pengembalian keuntungan yang dinikmati investor.

Hasil penelitian ini konsisten dengan hasil penelitian yang dilakukan oleh Indriani dan Dewi (2016), Hendrayana dan Yasa (2015), Lestari dan Hermanto (2015), Panjaitan dan Wardani (2016), Purnamasari et al. (2017), Purwasih dan Utomo (2010) serta Chairatanawan (2008) yang menyatakan bahwa semakin 
tinggi nilai return on asset yang dimiliki suatu perusahaan akan berdampak pada kenaikan harga saham bank. Nilai return on asset yang tinggi akan memberikan informasi positif terkait dengan kinerja keuangan perusahaan yang akan berdampak pada keputusan investasi yang dilakukan investor sehingga harga saham bank mengalami kenaikan.

Net interest margin berpengaruh positif terhadap perubahan harga bank. Hal ini berarti hipotesis keempat $\left(\mathrm{H}_{4}\right)$ dalam penelitian ini dapat diterima, yaitu semakin tinggi nilai net interest margin berdampak pada kenaikan harga saham bank.Net interest margin memeberikan informasi terkait kemampuan perusahaan dalam pengelolaan aktiva produktif yang dimiliki bank untuk menghasilkan pendapatan bunga bersih. Peningkatan net interest margin menandakan bahwa bank mampu meningkatkan pendapatan bunga bersih, sehingga dapat memperoleh tanggapan positif dari para pelaku pasar modal yang terlihat dari kenaikan harga sahamnya.

Hasil penelitian ini konsisten dengan hasil penelitian yang dilakukan oleh Wismaryanto (2013), Kurniadi (2012) serta Setyawan dan Mawardi (2012) yang menyatakan bahwa semakin tinggi nilai net interest margin yang dimiliki suatu perusahaan akan berdampak pada kenaikan harga saham bank. Semakin tingginya kemampuan bank dalam menghasilkan pendapatan bunga bersih akan membantu bank dalam mengantisipasi potensi kerugian dan meningkatkan modal sehingga bank dapat menjaga kinerja perusahaannya. Informasi ini akan menjadi sinyal postif bagi investor untuk berinvestasi yang berdampak pada kenaikan harga sahamnya. 
Ni Putu Desy Wulandara Cahyani dan I.G.A.M. Asri Dwija Putri. Pengaruh...

Capital adequacy ratio tidak berpengaruh terhadap perubahan harga saham bank. Hal ini berarti hipotesis kelima $\left(\mathrm{H}_{5}\right)$ dalam penelitian ini ditolak, yaitu besar kecilnya nilai capital adequacy ratio tidak mempengaruhi harga saham bank. Hasil penelitian ini berlawanan dengan hipotesis awal yang diajukan yaitu capital adequacy ratio berpengaruh positif pada perubahan harga saham bank.

Seluruh perusahaan perbankan yang menjadi sampel penelitian dapat menjaga kecukupan modalnya sesuai dengan batas minimum yang ditentukan Otoritas Jasa Keuangan yaitu sebesar 8\%. Pengawasan yang ketat terkait dengan kecukupan modal bank menjadikan bank akan selalu dalam kondisi yang baik dalam pengelolaan modalnya. Oleh karena itu informasi terkait dengan nilai capital adequacy ratio kurang mendapat respon dari investor, sehingga tidak memberikan dampak apapun terhadap perubahan harga saham bank. Hasil penelitian ini konsisten dengan penelitian yang dilakukan oleh Christie (2016), Setyawan dan Mawardi (2012) serta Jiwandono (2014) yang menemukan bahwa besar kecilnya nilai capital adequacy ratio tidak berpengaruh pada perubahan harga saham bank.

Secara umum hasil penelitian ini memberikan pemahaman mengenai pengaruh risk profile, good corporate governance, earning dan capital pada perubahan harga saham bank. Hal ini sudah sesuai dengan teori yang digunakan dalam penelitian ini yaitu signaling theory. Signaling theory menekankan pentingnya informasi- informasi yang terkait dengan kinerja perusahaan yang dikeluarkan perusahaan (agent) pada pengambilan keputusan investasi investor (principal). 
Risk profile berpengaruh negatif pada perubahan harga saham bank, yang sesuai dengan signaling theory. Hal ini membuktikan bahwa informasi terkait dengan risk profile perusahaan akan berdampak pada perubahan harga saham bank. Semakin rendah risiko yang dihadapi dan semakin tingginya penerapan manajemen risiko yang dilakukan, membuat kondisi bank lebih stabil dan tahan terhadap risiko yang muncul sekarang atau di masa depan.

Good corporate governance, return on asset dan net interest margin berpengaruh positif pada perubahan harga saham bank, yang sesuai dengan signaling theory. Penerapan tata kelola perusahaan yang baik, penerapan manajemen risiko dan kemampuan perusahaan untuk memperoleh laba dapat meningkatkan kinerja suatu perusahaan yang akan berdampak pada kenaikan harga saham bank.

Capital adequacy ratio tidak berpengaruh pada perubahan harga saham bank, hasil penelitian ini berlawanan dengan hipotesis awal yang diajukan. Pengawasan yang ketat terkait dengan kecukupan modal bank menjadikan bank akan selalu dalam kondisi yang baik dalam pengelolaan modalnya. sehingga informasi terkait dengan nilai capital adequacy ratio tidak memberikan dampak apapun terhadap perubahan harga saham bank.

Hasil penelitian ini diharapkan dapat memotivasi manajemen perusahaan untuk mempertahankan dan meningkatkan kinerjanya seperti kinerja keuangannya, tata kelola perusahaan dan penanganan risiko dalam perusahaan. Bank sebagai salah satu lembaga keuangan yang beroperasi berdasarkan kepercayaan masyarakat harus dapat mempertahankan dan meningkatkan 
Ni Putu Desy Wulandara Cahyani dan I.G.A.M. Asri Dwija Putri. Pengaruh...

kinerjanya sehingga investor tetap yakin untuk menanamkan modalnya. Semakin baik kinerja perusahaan maka semakin banyak investor yang ingin menanamkan modalnya pada saham perusahaan perbankan.

Selain manajemen perusahaan, hasil penelitian ini diharapkan dapat membantu investor dalam pengambilan keputusan investasi untuk memilih dan menilai bank mana yang memiliki kinerja yang baik. penilaian terhadap keadaan suatu perusahaan yang dalam penelitian ini menggunakan penilaian risk profile perusahaan, penerapan good corporate governance, kemampuan perusahaan dalam menghasilkan laba dan kemampuan perusahaan dalam mempertahankan kecukupan modalnya diperlukan untuk mendapat informasi yang akan digunakan sebagai referensi dalam pengambilan keputusan investasi agar memperoleh return yang maksimal.

\section{SIMPULAN}

Berdasarkan hasil penelitian yang diperoleh melalui pengujian statistik serta pembahasan seperti yang telah diuraikan pada bab sebelumnya, maka dapat disimpulkan bahwa risk profile berpengaruh negatif pada perubahan harga saham bank.Good corporate governance, return on asset dan net interest margin berpengaruh positif pada perubahan harga saham bank sertacapital adequacy ratio tidak berpengaruh terhadap perubahan harga saham bank.

Berdasarkan hasil penelitian dan simpulan di atas, saran yang dapat diberikan adalah sudah sewajarnya perusahaan perbankan perlu lebih tanggap dalam penerapan risk profile dan good corporate governance, tidak hanya unuk keuntungan perusahaan melainkan juga kepentingan nasabahnya. Dalam 
pelaksanaannya ternyata masih terdapat bank yang belum menerapkan dan mempublikasikan laporan terkait risk profile perusahaan dan good corporate governance serta terdapat beberapa perusahan perbankan yang hasil penerapannya masih kurang memadai. Bank sebagai salah satu lembaga keuangan yang beroperasi berdasarkan kepercayaan masyarakat, harus terus menjaga kinerjanya untuk menumbuhkan persasaan aman dalam berinvestasi dalam bank tersebut. Investor tentu akan tertarik menanamkan modalnya pada bank yang penanganan risiko dan pelaksanaan good corporate governance yang dilakukan dengan baik sehingga dapat meningkatkan nilai perusahaannya.

Peneliti selanjutnya dapat mengembangkan penelitian ini dengan menambah variabel penelitian yang dapat mempengaruhi harga saham bank. Hal ini terlihat dari nilai koefisien determinasi sebesar 0,648 berarti bahwa 64,8\% variansi kemungkinan terjadinya perubahan harga saham dipengaruhi oleh variabel risk profile, good corporate governance, return on asset, net interest margin dan capital adequacy ratio sedangkan sisanya sebesar 35,2\% dijelaskan oleh variabel lain yang tidak dimasukkan dalam model.

\section{REFERENSI}

Annisa, R., \& Wardhani, R. (2014). Analisis Pengaruh Struktur Good Corporate Governance Dan Kinerja Terhadap Risiko Kredit Perbankan. Finance And Banking Journal, 16(1), 1-16.

Bahri, M. F. (2014). Net Interest Margin , Operational Efficiency Ratio, Liquidity To Debt Ratio Terhadap Return On Assets. Jurnal Akuntansi, 2(2), 55-63.

Chairatanawan, Y. (2008). Predictive Power Of Financial Ratios To Stock Return Thailand. Citeseer, 2(2), 113-120.

Christie, J. (2016). Pengaruh Capital, Assets, Management, Earnings, Liquidity Dan Sensitivity Of Market (Camels) Terhadap Return Saham Pada Perusahaan Perbankan Go Public. Jurnal Riset Bisnis Dan Manajemen, 4(2), 
99-114.

Goyal, K. A., \& Agrawal, S. (2010). Risk Management In Indian Banks :Some Emerging Issues. The Indian Economic Journal, 1(1), 102-109.

Hendrayana, P., \& Yasa, G. W. (2015). Pengaruh Komponen Rgec Pada Perubahan Harga Saham Perusahaan Perbankan Di Bursa Efek Indonesia. EJurnal Akuntansi Universitas Udayana, 10(2), 554-569.

Indriani, N., \& Dewi, S. K. S. (2016). Pengaruh Variabel Tingkat Kesehatan Bank Terhadap Harga Saham Perbankan Di Bursa Efek Indonesia. E-Jurnal Manajemen Universitas Udayana, 5(5), 2756-2785.

infobank. 2016. NIM Ditekan Laba Melorot. Diunduh tanggal 28 Januari 2018, http://infobanknews.com/nim-ditekan-laba-bank-melorot/.

2016. OJK Tak Batasi NIM. Diunduh tanggal 28 Januari 2018, http://infobanknews.com/ojk-tak-batasi-nim/.

Jiwandono, T. (2014). Analisis Faktor Fundamental Terhadap Harga Saham Sektor Perbankan Yang Go Public Di Indeks Kompas 100. Jurnal Ilmu Manajemen, 2(3), 783-794.

Kurniadi, R. (2012). Pengaruh Car, Nim, Ldr Terhadap Return Saham Perusahaan Perbankan Indonesia. Accounting Analysis Journal, 1(1), 7-11.

Lestari, S. D., \& Hermanto, S. B. (2015). Pengaruh Capital, Asset, Earning Dan Liquidity Terhadap Perubahan Harga Saham Bank. Jurnal Ilmu Dan Riset Akuntansi, 4(9), 1-22.

Luu, T. B. N., Luu, T. T., \& Luu, H. M. (2013). Corporate Governance And Stock Price. Journal Ho Chi Minh City Pedagogical University Science Magazine, 46, 144-152.

Mohammed, H. K., \& Knápková, A. (2016). The Impact Of Total Risk Management On Company's Performance. Procedia Social And Behavioral Science, 220, 271-277.

Muhammad, N., \& Scrimgeour, F. (2014). Stock Returns And Fundamentals In The Australian Market. Asian Journal Of Finance \& Accounting, 6(1), 271290.

Panjaitan, H. P., \& Wardani, D. P. K. (2016). Pengaruh Tingkat Kesehatan Bank Dengan Menggunakan Metode Rgec (Risk Profile, Gcg, Earning, Dan Capital) Terhadap Harga. Procuratio, 4(2), 253-271.

Purnamasari, D., Nuraina, E., \& Astuti, E. (2017). Pengaruh Capital Adequacy Ratio, Loan To Deposit Ratio Dan Return On Asset Terhadap Harga Saham Perusahaan Perbankan. Fipa: Forum Ilmiah Pendidikan Akuntansi Universitas Pgri Madiun, 5(1), 264-277. 
Purwasih, R., \& Utomo, D. C. (2010). Pengaruh Rasio Camel Terhadap Perubahan Harga Saham Perusahaan Perbankan Yang Go Public Di Bursa Efek Indonesia (Bei) Tahun 2006-2008. Skripsi Fakultas Ekonomi Universitas Diponegoro Semarang.

Satria, I., \& Hatta, I. H. (2015). Pengaruh Kinerja Keuangan Terhadap Harga Saham 10 Bank Terkemuka Di Indonesia. Jurnal Akuntansi Universitas Tarumanegara, 19(2), 179-196.

Setyawan, A. W. P., \& Mawardi, W. (2012). Pengaruh Komponen Risk Based Bank Rating Terhadap Harga Saham Perusahaan Perbankan Yang Go Public Di Bursa Efek Indonesia (Bei) Tahun 2008-2011. Skripsi Fakultas Ekonomika Dan Bisnis Universitas Diponegoro Semarang.

Widyaningrum, \& Asih, H. (2014). Analisis Tingkat Kesehatan Bank Dengan Menggunakan Metode Risk-Based Bank Rating (Rbbr) (Studi Pada Bank Yang Terdaftar Di Bursa Efek Indonesia Dalam Ihsg Sub Sektor Perbankan Tahun 2012). Jurnal Administrasi Bisnis, 9(2).

Winarsih. (2016). Analisis Tingkat Kesehatan Bank Berdasarkan Risk-Based Bank Rating Dan Pengaruhnya Terhadap Harga Saham. Jurnal Akuntansi Indonesia, 3(1), 71-80.

Wismaryanto, S. D. (2013). Pengaruh NPL, LDR, ROA, ROE, NIM, BOPO, dan CAR terhadap Harga Saham Pada Sub Sektor Perbankan yang Terdaftar di Bursa Efek Indonesia Tahun 2008-2012. Jurnal Manajemen, 3(1), 29-60. 